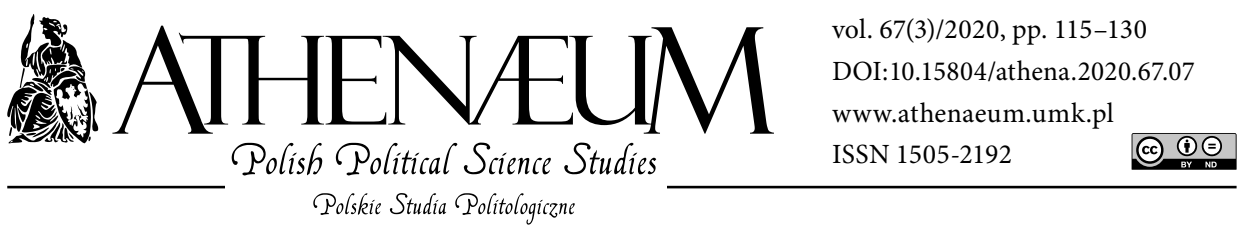

\title{
ENVIRONMENTAL AWARENESS AMONGST YOUTH IN TIMES OF CLIMATE CRISIS
}

\author{
ŚWIADOMOŚĆ EKOLOGICZNA MŁODZIEŻY \\ W DOBIE KRYZYSU KLIMATYCZNEGO \\ Izabela Kapsa*๑, Wojciech Trempała**๑
}

\begin{abstract}
This article deals with the important issue of environmental awareness amongst youth in times of climate crisis. Environmental awareness has been measured basing on the currently dominant division into anthropocentrism and biocentrism, the main two positions on the place of man in nature, the value of nature, including its moral significance and the assessment of human impact on environmental safety. The results come from surveys conducted in 2018 and 2019 in Poland (in the city of Bydgoszcz) on high school students (approximately 18 years old). The research presents young people's opinions on environmental protection, the role of man in relation to nature (identified as biocentric or anthropocentric), and the threats associated with the climate crisis. We also analyse how environmental awareness is influenced by the content of media messages. Our results show that the surveyed students declare biocentric/anti-anthropocentric beliefs more often than anthropocentrism, and this tendency
\end{abstract}

Artykuł podejmuje ważny problem świadomości ekologicznej młodzieży w dobie kryzysu klimatycznego. Zawiera analizę wyników badań empirycznych przeprowadzonych w 2018 i 2019 roku w Polsce (miasto: Bydgoszcz), w wyniku których poglądy młodych na temat kryzysu klimatycznego, postrzegania ochrony środowiska i kategorii człowieka w relacji z naturą dostarczyły danych pozwalających na ulokowanie ich na skali biocentrycznej lub antropocentrycznej. Ponadto zaprezentowane są informacje dotyczące postrzegania przez młodych ludzi kryzysu klimatycznego w kategorii zagrożenia współczesnego świata. W tym celu zaprezentowano statystyki opisowe i badanie związku między zmiennymi, które ponadto służą odpowiedzi na pytanie, czy stan świadomości ekologicznej zmienia się pod wpływem treści komunikatów medialnych. Jak wynika z przeprowadzonych przez autorów badań, na poziomie deklaracji badani maturzyści przejawiają predyspozycję do silniejszej akcepta-

* Kazimierz Wielki University in Bydgoszcz, Faculty of Political Science and Administration.

** Kazimierz Wielki University in Bydgoszcz, Faculty of Political Science and Administration. 
was reinforced by the growing presence of discussions surrounding climate change and related threats in public discourse.

Keywords: climate crisis; ecological threats; environmental awareness of young people; environmental protection; youth's perception of the climate crisis as a threat cji przekonań biocentrycznych/antyantropocentrycznych niż antropocentryzmu i tendencja ta wzmacnia się wraz z nasilaniem się dyskursu publicznego na temat zmian klimatu i zagrożeń związanych z kryzysem środowiskowym.

Słowa kluczowe: kryzys klimatyczny; zagrożenia ekologiczne; świadomość ekologiczna młodzieży; ochrona środowiska; postrzeganie przez młodych ludzi kryzysu klimatycznego jako zagrożenia

\section{INTRODUCTION}

Although the general public has been aware of various environmental threats for years, awareness of the climate crisis has only begun growing recently. Interestingly, young people in previous decades were known for having the strongest pro-environmental opinions and attitudes. The results of surveys conducted in Poland and all over the world indicate that youth, young adults, urban dwellers, women and those with a university degree have a higher environmental awareness than other groups (e.g.: Dunlap \& Catton, 1979; McMillan et al., 1997; Dunlap et al., 2000; Burger, 2005; Aminrad, Zakaria, \& Hadi, 2011). Nowadays, we may observe that young age is not currently the principle demographic in regard to environmental awareness. In the report of the Polish Ministry of Environment (entitled Adaptation to Climate Change, see: Badania świadomości ekologicznej, 2018), the question - "Have you personally done anything over the last six months to limit the effects of extreme weather events?" - was given a positive answer by respondents aged $25-34$ years $(12.6 \%)$ and $45-59$ years $(11.6 \%)$, while for the youngest (15-24) this was only $7.4 \%$, the lowest rate among all age groups. Yet, as their attitude seems to be changing with the growing prevalence of media reports on climate strikes or Greta Thunberg's actions, as well as numerous comments linking COVID-19 pandemic with human neglect of nature, it may be expected that for new generations the problem of environmental protection may eventually become very important or even crucial to be solved. We see some similarity in this matter to the environmental and pacifist revolution of the $1960^{\mathrm{s}}$ and 1970s. This similarity is not so much about just taking action because the way of communication and mobilization basing on new technologies has changed a lot, but we notice that similar to the end of the $20^{\text {th }}$ century, the way of thinking about the need to protect the environment is changing in general 
because media (also electronic) are tackling this issue. This is why one of the aims of this paper is to investigate the relationship between content published in the media and the state of ecological awareness of young people. The open question is whether the access to the information regarding the environmental issues in the era of information society is sufficient to shape ecological attitudes. However, it is necessary to raise this topic especially when neither the education system nor domestic habits promote environmental attitudes sufficiently.

It is worth emphasizing that the report by the United Nations Secretary General U Thant (1969), following the first conference organized under the aegis of the UN in Stockholm (1972) and the publication of the reports to the Club of Rome (1972 and 1974), sparked great interest in the issue of the environmental crisis in the world of politics, science, media and, consequently, among ordinary people around the world. This also applied to communist Poland, whose authorities reacted especially enthusiastically to U Thant's report. According to Tadeusz Burger (2005, p. 24), "the authorities of the People's Republic of Poland relatively quickly recognized that the state of the environment is a very fashionable problem, which would allow to show that a communist state, representing the best of all political systems, boldly responds to the challenges of the modern world. To Polish decision-makers, the environmental issue also seemed far less risky than, for example, human rights or the free flow of information or freedom of speech". National empirical research on environmental awareness in Poland shows a shift towards pro-environmental attitudes from the youth in reports from the $1980^{\text {s }}$ to the middle-aged respondents in the $21^{\text {st }}$ century (Gliński, 1988; Burger, 1992; Burger \& Sadowski, 1994; Burger, 1997; Burger, 2000; Fudali, 2002; Burger, 2005; Bołtromiuk, 2009). This indicates a "cohort effect" and the existence of a "generation of ecological breakthrough" in Polish society. The intensified media focus on the climate crisis and the emergence of new social green movements indicate that the current generation of youth may become the generation of "the climate breakthrough" or the group which directly experiences the effects of "the environmental crisis" as defined at the turn of the 1960s and 1970s.

The main aim of this article is to present the results of research on environmental awareness amongst youth at a time when the climate crisis has become an important element of public debate. The results come from the original survey aimed at identifying young people's view on ecological issues. Based on the fact that the survey was conducted twice (in 2018 and 2019), we performed a comparative analysis between these two years. In addition, we analysed the relationship between environmental awareness, expressed in one of two cat- 
egories - anthropocentric or biocentric, and the perception of climate crisis as a threat. In our opinion, knowledge of environmental threats may serve as the basis for building attitudes and behaviours among young people that could help prevent further degradation of the environment.

\section{METHODS AND RESEARCH QUESTIONS}

The results of the empirical research presented in this article come from the project: "Attitudes of secondary school graduates in Bydgoszcz", carried out by an interdisciplinary team of pedagogues, political scientists and sociologists from the Kazimierz Wielki University in Bydgoszcz. Its main objective was the diagnosis of a wide longitudinal spectrum of environmental awareness in the generation entering early adulthood. An original questionnaire was constructed to measure life orientation, social and civic participation, political knowledge and preferences, social distance towards selected groups, attitudes towards education and school, system of values, perception of a hierarchy of threats or ecological beliefs. The theoretical validity of the positions of the questionnaire was assessed by three independent experts in environmental ethics. The reliability of the overall scale A versus B was estimated using Cronbach's alpha (2018: $\alpha=0.88 ; 2019$ : $\alpha=0.87$ ). Due to the fact that the survey was carried out at secondary schools, the questionnaire was also checked for content and accessibility by teachers as well as by methodologists from the Municipal Teacher Education Centre in the city of Bydgoszcz where the measurements were conducted.

The results presented in the article come from two surveys. The first one was conducted in the school year 2017/2018 (in short: 2018) with $262 \sim 18$ year old students in their final year of high school (about $10 \%$ of all final year students in the schools covered by the survey), while in 2018/2019 (in short 2019) it was conducted on 392 students (approx. 15\%). The selected method of quota sampling in both editions of the survey reflected the actual proportions in terms of school type and gender in the surveyed schools. It means that if in 2018 the proportion between the number of students in general and vocational education schools were 58\%:42\%, in our survey the similar number of students from each type of school took part (55\%:45\%). In 2019, we obtained an exact reflection of this proportion - it was 56\%:44\%. We also considered the profile of education, keeping the numbers reflecting humanities and science students. Regarding to gender, in both editions it was roughly half and half, what we also achieved in 
our survey. The survey was conducted in Bydgoszcz (Poland), a city of about 350,000 inhabitants.

The two editions of the questionnaire differed slightly in the number of questions and possible answers. In the 2018 survey, the students were asked to respond to 40 statements, compared to 33 in 2019 . Our comparative analysis concerned the same 19 statements included in both surveys. The respondents determined the level of compliance with the statements given in the table using a scale based on Rensis Likert's model (I strongly agree, I agree, etc.). In the question on threats related to safety, respondents could indicate answers on their own (in an openended question). The results presented in the article are based on the statistical analysis, mainly descriptive statistics.

In our study, the notion of "environmental awareness" is based on the definition of Andrzej Papuziński (2006) who describes it as: "a part of social awareness referring to information and beliefs regarding the natural environment and the perception of the relationship between the condition of the environment and the conditions and quality of human life, especially in the matter of ecological threats".

Therefore, we focus primarily on the perception of the condition of the environment, human relations with nature, as well as knowledge about ecological threats. Our scale of ecological awareness was based on the currently dominant division in environmental ethics into anthropocentrism and biocentrism (Table 1), the main two positions on the place of man in nature, the value of nature including its moral significance, and the assessment of human impact on environmental safety (Ciążela, 2009; Ganowicz-Bączyk, 2009; Kortenkamp \& Moore, 2001). The anthropocentric position is well embedded within the humanistic philosophical tradition, while the biocentric position, where the human species is not perceived as superior to other living beings, is sometimes referred to as yet another example of a human point of view, and so it is more accurate to describe the opposition to anthropocentrism as anti-anthropocentrism (Skolimowski, 1984). Therefore, in order to maintain methodological accuracy in this study, the notion of "biocentrism" was supplemented with "anti-anthropocentrism".

The results of the analysis were based on descriptive statistics and focused on the following research questions contained in the study:

1) What is the environmental awareness of the surveyed youth?

2) Do the studied youth manifest anthropocentric or biocentric orientation in their perception of nature? 
Table 1. Images of Nature in Human Attitudes by Anthropocentric and Biocentric/ Anthropocentric Positions

\begin{tabular}{|c|c|}
\hline Extreme Anthropocentrism & Biocentrism/Anti-anthropocentrism \\
\hline $\begin{array}{l}\text { 1) Only man creates the value of the world around } \\
\text { him. } \\
\text { 2) Only man knows and has knowledge of the } \\
\text { world. } \\
\text { 3) Only human beings have an intrinsic value in } \\
\text { and of themselves. } \\
\text { 4) Man is the measure of all things. } \\
\text { 5) Man has an unlimited right to use natural } \\
\text { resources and living space, because nature was } \\
\text { created or evolved for him. }\end{array}$ & $\begin{array}{l}\text { 1) Not only human beings, but also non-human } \\
\text { beings have an inner value. } \\
\text { 2) Not only man, but also non-human beings } \\
\text { realize their own vital values and know how to } \\
\text { live according to their own nature. } \\
\text { 3) Every living creature is a measure of those } \\
\text { aspects of the environment with which it } \\
\text { interacts in order to live. } \\
\text { 4) The biosphere should not be exploited and } \\
\text { managed solely for human interests. }\end{array}$ \\
\hline
\end{tabular}

Source: authors' own elaboration based on Z. Piątek, 1998, p. 11-12.

3) Is the awareness of threats resulting from the climate crisis connected with anthropocentric or biocentric orientation?

4) Where are ecological threats located in the spectrum of threats to the modern world in young people's minds?

5) Does the media influence the perception of ecological threats?

\section{RESULTS}

Table 2 presents descriptive statistics regarding young people's perception of nature, manifested in either anthropocentric or biocentric orientation. The intensity of anthropocentric or biocentric attitudes is presented in Table 3 . The tables show that environmental awareness among young people is dominated by the predominance of biocentric/anti-anthropocentric orientation over anthropocentrism. Moreover, in 2019, significantly more respondents (52.87\%) fell within the categories of moderate and extreme biocentrism compared to 2018 (34.47\%). Overall, the surveyed youth expressed the conviction that man occupies the highest position in the hierarchy of beings and is the most exceptional of all living beings on Earth. Nevertheless, these beliefs cannot justify, according to the respondents, an abuse of the privileged and dominant position of the human species in relation to nature. Nor did they have a strong belief that new technologies, progress and science are the remedy for the environmental crisis. Moreover, the 
respondents were much more inclined to perceive the value of nature in autotelic rather than instrumental terms.

Table 2. Scale: Anthropocentrism vs. Biocentrism

\begin{tabular}{|c|c|c|c|c|c|c|c|}
\hline Anthropocentric statements & Year & $\mathrm{SA}^{*}$ & A & NO & $\mathrm{D}$ & SD & Median \\
\hline \multirow{2}{*}{$\begin{array}{l}\text { In the hierarchy of beings, human } \\
\text { occupies the highest place among all } \\
\text { living beings inhabiting the Earth. }\end{array}$} & 2018 & 51.26 & 25.63 & 15.2 & 5.04 & 2.94 & 1 \\
\hline & 2019 & 45.2 & 30.64 & 11.68 & 7.01 & 5.19 & 2 \\
\hline \multirow{2}{*}{$\begin{array}{l}\text { Thanks to science, human will be able } \\
\text { to fully control nature, and thus ensure } \\
\text { the safety of life on Earth. }\end{array}$} & 2018 & 18.48 & 23.94 & 30.67 & 20.16 & 6.72 & 3 \\
\hline & 2019 & 11.2 & 28.64 & 22.13 & 25.78 & 12.24 & 3 \\
\hline \multirow{2}{*}{$\begin{array}{l}\text { For the sake of economic development, } \\
\text { the natural environment should be } \\
\text { transformed as much as possible. }\end{array}$} & 2018 & 7.17 & 11.39 & 26.16 & 26.58 & 28.69 & 4 \\
\hline & 2019 & 5.20 & 9.89 & 19.01 & 29.42 & 36.45 & 4 \\
\hline \multirow{2}{*}{$\begin{array}{l}\text { Man, due to his abilities and skills, is } \\
\text { the most unique species inhabiting the } \\
\text { Earth. }\end{array}$} & 2018 & 32.35 & 24.36 & 25.21 & 12.18 & 5.88 & 2 \\
\hline & 2019 & 33.16 & 25.58 & 16.97 & 13.83 & 10.44 & 2 \\
\hline \multirow{2}{*}{$\begin{array}{l}\text { Man has no moral obligations towards } \\
\text { nature. }\end{array}$} & 2018 & 5.51 & 6.35 & 21.61 & 31.78 & 34.74 & 4 \\
\hline & 2019 & 3.12 & 4.68 & 15.36 & 23.43 & 53.38 & 5 \\
\hline \multirow{2}{*}{$\begin{array}{l}\text { Man, because of his superiority to other } \\
\text { living beings, has the full right to rule } \\
\text { over nature. }\end{array}$} & 2018 & 7.26 & 10.68 & 27.7 & 25.64 & 28.63 & 4 \\
\hline & 2019 & 6.8 & 8.64 & 17.01 & 26.7 & 40.83 & 4 \\
\hline \multirow{2}{*}{$\begin{array}{l}\text { The development of modern technolo- } \\
\text { gies is safe, because in the near future } \\
\text { it will allow people to fully control the } \\
\text { laws of nature. }\end{array}$} & 2018 & 8.93 & 12.76 & 40.85 & 24.68 & 12.76 & 3 \\
\hline & 2019 & 4.94 & 12.76 & 25.26 & 35.15 & 21.87 & 4 \\
\hline \multirow{2}{*}{$\begin{array}{l}\text { Increasing the material well-being of } \\
\text { humanity is much more important } \\
\text { than nature's well-being. }\end{array}$} & 2018 & 6.83 & 10.25 & 34.61 & 27.77 & 20.51 & 3 \\
\hline & 2019 & 1.82 & 7.81 & 24.74 & 32.03 & 33.6 & 4 \\
\hline \multirow{2}{*}{$\begin{array}{l}\text { Nature is of value only in so far as it is } \\
\text { a source of benefit for human life. }\end{array}$} & 2018 & 5.95 & 11.06 & 37.44 & 26.81 & 18.72 & 3 \\
\hline & 2019 & 2.88 & 4.97 & 21.46 & 30.36 & 40.31 & 4 \\
\hline \multirow{2}{*}{$\begin{array}{l}\text { The meaning of all life on Earth should } \\
\text { be determined by man. }\end{array}$} & 2018 & 6.81 & 17.02 & 34.46 & 25.11 & 16.59 & 3 \\
\hline & 2019 & 3.9 & 10.67 & 25.26 & 25.52 & 34.63 & 4 \\
\hline \multirow{2}{*}{$\begin{array}{l}\text { The extraction of natural resources } \\
\text { should not be restricted in the name of } \\
\text { environmental protection. }\end{array}$} & 2018 & 10.72 & 16.73 & 39.48 & 21.46 & 11.58 & 3 \\
\hline & 2019 & 4.97 & 9.68 & 23.56 & 26.96 & 34.81 & 4 \\
\hline \multirow{2}{*}{$\begin{array}{l}\text { Plants and animals do not have their } \\
\text { own rights. Only human beings have } \\
\text { rights. }\end{array}$} & 2018 & 6.46 & 6.89 & 36.2 & 14.65 & 35.77 & 4 \\
\hline & 2019 & 6.02 & 5.49 & 17.27 & 26.96 & 44.24 & 4 \\
\hline
\end{tabular}




\begin{tabular}{|c|c|c|c|c|c|c|c|}
\hline Biocentric statements & Year & SD & $\mathrm{D}$ & NO & A & SA & Median \\
\hline \multirow{2}{*}{$\begin{array}{l}\text { Plants and animals, like humans, have } \\
\text { their rights. }\end{array}$} & 2018 & 3.78 & 6.72 & 13.86 & 29.83 & 45.8 & 4 \\
\hline & 2019 & 3.64 & 4.95 & 11.45 & 32.29 & 47.65 & 4 \\
\hline \multirow{2}{*}{$\begin{array}{l}\text { Nature has value through the very fact } \\
\text { of its existence. }\end{array}$} & 2018 & 2.54 & 1.69 & 20.33 & 33.9 & 41.52 & 4 \\
\hline & 2019 & 0.78 & 1.83 & 10.99 & 27.75 & 58.63 & 5 \\
\hline \multirow{2}{*}{$\begin{array}{l}\text { The natural world does not exist solely } \\
\text { because of human needs. }\end{array}$} & 2018 & 2.54 & 5.93 & 19.91 & 32.2 & 39.4 & 4 \\
\hline & 2019 & 2.88 & 5.23 & 14.66 & 19.37 & 57.85 & 5 \\
\hline \multirow{2}{*}{$\begin{array}{l}\text { The development of new technologies } \\
\text { is dangerous, as it will soon lead to the } \\
\text { extinction of many species of plants } \\
\text { and animals. }\end{array}$} & 2018 & 8.05 & 15.68 & 26.69 & 27.12 & 22.45 & 3 \\
\hline & 2019 & 7.55 & 15.62 & 19.27 & 31.25 & 26.3 & 4 \\
\hline \multirow{2}{*}{$\begin{array}{l}\text { The meaning of all life on Earth is } \\
\text { equally determined by the existence of } \\
\text { man, animals, and plants. }\end{array}$} & 2018 & 2.55 & 5.95 & 28.08 & 24.68 & 38.72 & 4 \\
\hline & 2019 & 3.91 & 7.31 & 22.45 & 33.94 & 32.37 & 4 \\
\hline \multirow{2}{*}{$\begin{array}{l}\text { Human conduct should take into } \\
\text { account the interests of animals and } \\
\text { plants. }\end{array}$} & 2018 & 4.29 & 6.43 & 27.89 & 27.89 & 33.47 & 4 \\
\hline & 2019 & 3.91 & 2.87 & 13.31 & 32.9 & 46.99 & 4 \\
\hline \multirow{2}{*}{$\begin{array}{l}\text { The abilities and skills possessed by } \\
\text { humans do not make them a better } \\
\text { species than other living beings (other } \\
\text { animal or plant species). }\end{array}$} & 2018 & 9.44 & 18.02 & 30.9 & 22.31 & 18.45 & 3 \\
\hline & 2019 & 8.09 & 16.45 & 26.89 & 22.19 & 26.37 & 3 \\
\hline Average score for all statements & Mean & Min & $\operatorname{Max}$ & $\begin{array}{l}\text { Me- } \\
\text { dian }\end{array}$ & \multicolumn{3}{|c|}{ Cronbach's alpha } \\
\hline 2018 & 64.2 & 25 & 89 & 64 & \multicolumn{3}{|c|}{0.88} \\
\hline 2019 & 70.14 & 34 & 95 & 71 & \multicolumn{3}{|c|}{0.87} \\
\hline
\end{tabular}

In addition, the 2019 survey included the issue of climate change. Less than $55 \%$ of respondents believed that climate change is the most serious problem in the modern world (24.07\% did not agree with this statement, and $21.2 \%$ had no opinion). A willingness to pay high taxes to halt climate change was made by $35.43 \%$ of respondents (38.05\% rejected this claim and $26.51 \%$ had no opinion). As many as $62 \%$ of respondents believed that Poland should resign from coal in favor of renewable energy sources (only 16\% were against, and $22.04 \%$ had no opinion). Interestingly, the ruling party at that time in Poland declared a different position (see: Expose Morawieckiego..., 2017). However, only $12.08 \%$ of respondents did not eat meat for moral reasons (12.33\% had no opinion, and $75.6 \%$ had a different opinion; however, we do not know whether these two groups included 
those who did not eat meat for reasons other than morality). Only $12.83 \%$ of respondents believed that climate change is a lie used by international elites to multiply their own profits at the expense of ordinary people (although as much as $30 \%$ had no opinion on this issue).

Attitudes to climate change (recognizing climate change as the most serious problem in the modern world) were not related to the position on the scale of anthropocentric attitudes vs. anti-anthropocentric/biocentric attitudes $\left(\mathrm{r}_{\mathrm{s}}=\right.$ 0,$222 ; \mathrm{p}<0,001$; the scale is presented in Table 3). However, those who were willing to pay higher taxes to halt climate change showed stronger degrees of anti-anthropocentric/biocentric attitudes than those who were not $\left(r_{s}=0,357\right.$; $\mathrm{p}<0,001)$. The participants who declared that Poland should give up coal-fired power generation in favor of renewable energy sources also showed stronger anti-anthropocentric/biocentric attitudes than people who did not agree with that statement $\left(r_{s}=0,301 ; p<0,001\right)$. The same applies to the conviction that climate change is not a lie used by international elites to multiply their own profits at the expense of ordinary people; the greater the conviction, the stronger the tendency to support anti-anthropocentric/biocentric orientation $\left(r_{s}=0,385\right.$; $\mathrm{p}<0,001)$. However, there was no statistically significant correlation between not eating meat for moral reasons and the respondents position on the scale of anthropocentric vs. anti-anthropocentric/biocentric attitudes $\left(r_{s}=0,073\right.$; $\mathrm{p}>0,01)$.

Further information on the perception of the climate crisis as an important problem of the contemporary world was provided by an open-ended question where we asked the respondents to indicate the three largest safety threats in the world (ranked from the largest to the smallest). It is worth noting that Polish government survey (e.g., survey of environmental awareness available) have so far showed a low position of environmental threats, i.e., $12^{\text {th }}$ place in 2014 (with only $8 \%$ of respondents indicating environmental protection as an important problem to be solved by Poland), followed by $7^{\text {th }}$ place in 2018 (based on $18 \%$ of respondents). This survey is a cyclical study of Poles' awareness and ecological behavior, taking into account such problems as the biggest challenges for Poland in the context of the environment, natural environment and its protection, air quality, waste management, climate change, individual actions and behaviors supporting environmental protection. However, our study shows a very distinct difference between the indications of the respondents in 2018 and 2019. The respondents in 2019 indicated a much larger number - more indications for 
Table 3. The Intensity of Environmental Beliefs Measured on the AnthropocentricBiocentric/Anti-anthropocentric Scale and the Perception of Environmental Threats

\begin{tabular}{|l|c|c|c|c|c|c|}
\hline & \multicolumn{2}{|l|}{$\begin{array}{l}\text { Percentage of indi- } \\
\text { cations of ecological } \\
\text { threats among the three } \\
\text { main threats to security } \\
\text { intensity of beliefs on } \\
\text { in the } \\
\text { the entire population of } \\
\text { respondents }\end{array}$} & $\begin{array}{l}\text { Percentage of the } \\
\text { indication of ecological } \\
\text { threats in relation to } \\
\text { the group size of each } \\
\text { orientation }\end{array}$ \\
\cline { 2 - 8 } & 2018 & 2019 & 2018 & 2019 & 2018 & 2019 \\
\hline $\begin{array}{l}\text { Extreme } \\
\text { anthropocentrism }\end{array}$ & $3.36 \%$ & $0.26 \%$ & $0 \%$ & $0 \%$ & $0 \%$ & $0 \%$ \\
\hline $\begin{array}{l}\text { Moderate } \\
\text { anthropocentrism }\end{array}$ & $3.36 \%$ & $1.3 \%$ & $0 \%$ & $2.32 \%$ & $0 \%$ & $20 \%$ \\
\hline $\begin{array}{l}\text { Ambivalent with } \\
\text { a tendency towards } \\
\text { anthropocentrism }\end{array}$ & $17.22 \%$ & $13.54 \%$ & $7.3 \%$ & $9.3 \%$ & $2.89 \%$ & $7.4 \%$ \\
\hline $\begin{array}{l}\text { Ambivalence/ } \\
\text { Indifference }\end{array}$ & $8.82 \%$ & $3.64 \%$ & $3.63 \%$ & $1.55 \%$ & $2.89 \%$ & $4.76 \%$ \\
\hline $\begin{array}{l}\text { Ambivalent with } \\
\text { a tendency towards } \\
\text { biocentrism/ } \\
\text { anti-anthropocentrism }\end{array}$ & $32.77 \%$ & $28.38 \%$ & $45.45 \%$ & $27.13 \%$ & $9.68 \%$ & $10.51 \%$ \\
\hline $\begin{array}{l}\text { Moderate biocentrism/ } \\
\text { anti-anthropocentrism }\end{array}$ & $27.73 \%$ & $36.20 \%$ & $34.55 \%$ & $37.98 \%$ & $8.67 \%$ & $11.5 \%$ \\
\hline $\begin{array}{l}\text { Extreme biocentrism/ } \\
\text { anti-anthropocentrism }\end{array}$ & $6.74 \%$ & $16.67 \%$ & $9.07 \%$ & $21.70 \%$ & $9.25 \%$ & $33.33 \%$ \\
\hline
\end{tabular}

particular categories as well as more new categories in the area of environmental protection than in the previous year.

The threats indicated in the survey in 2018 included the following categories: $\mathbf{1}^{\text {st }}$ place - global warming (1 indication), smog (1) and natural disaster (1); $2^{\text {nd }}$ place - environmental pollution (11), natural disasters (7), waste (2), smog (2), ozone depletion (1), global warming (2), consumption of raw materials (2); $3^{\text {rd }}$ place - natural disasters (11), pollution (7), global warming (2), depletion of natural resources (2), disrespect for nature (1), smog (1), $\mathrm{CO}_{2}$ emissions (1). In total, in 2018, threats mentioned in $1^{\text {st }}$ place included 3 environmental categories, compared to 27 in $2^{\text {nd }}$ place, and 25 in $3^{\text {rd }}$ place.

Among the threats indicated in the survey in $2019, \mathbf{1}^{\text {st }}$ place included global warming (8), climate change (8), natural disasters (8), environmental pollution 
(5), depletion of natural resources (1); $2^{\text {nd }}$ place included environmental pollution (22), environmental disasters (12), climate change (6), global warming (4), natural disasters (3), smog (1), ozone depletion (2), depletion of resources (1); and $3^{\text {rd }}$ place: pollution (18), climate change (13), natural disasters (11), depletion of natural resources (3), global warming (2), and smog (1).

In total, in 2019 as many as 30 environmental threats were indicated in $1^{\text {st }}$ place (10 times more than in the previous year), 51 in $2^{\text {nd }}$ place (almost twice as many as in 2018), and 48 threats in $3^{\text {rd }}$ place (also almost twice as many as in 2018). Interestingly, when asked to indicate the 3 most important values in life, in 2018 the respondents did not indicate any values related to nature at all, and in 2019 one person indicated the beauty of the world and nature in $3^{\text {rd }}$ place. It is worth noticing that the respondents with a biocentric worldview more frequently pointed out ecological threats among the most important threats to security in the modern world. In 2018, as much as $89 \%$ and in 2019 over $86 \%$ of such indications came from people whose biocentric/anti-anthropocentric beliefs domineered over their anthropocentric opinions. This does not mean, however, that biocentric/anti-anthropocentric beliefs were always, or even significantly, correlated with an awareness of environmental problems - these were relatively rarely mentioned by young people in our study. In 2018, among respondents with a biocentric/anti-anthropocentric orientation, approximately one in ten of all indications concerned environmental threats. Among those with an anthropocentric orientation as well as ambivalent people, they were almost non-existent. The situation was slightly different in 2019. Among the representatives of extreme biocentrism/anthropocentrism, one in three threats mentioned was related to environmental issues (33.3\%). In ambivalent people with a predominance of biocentric/anti-anthropocentric beliefs and moderately biocentric/anti-anthropocentric respondents, environmental threats still accounted for about $10 \%$ of all declarations. The results of respondents with an ambivalent orientation, albeit with a tendency towards anthropocentric attitudes, were also similar in this case and higher by almost $5 \%$ in comparison to the previous edition. It is also interesting that environmental threats constituted $20 \%$ of all threats listed by respondents in the moderate anthropocentric range. However, it is difficult to form unambiguous conclusions in this respect due to the small size of this group compared to the entire population.

The visible increase in the indications of environmental threats may have been related to several important events covered extensively by the press (including electronic media). In 2018, the city of Bydgoszcz - where the research was 
conducted - launched numerous initiatives to counteract smog and the public was extensively informed on the exposure to pollution from Zachem, a local chemical plant. These were both the activities of public services, e.g., the municipal police, as well as grassroots initiatives of the residents. Similar initiatives were also being undertaken in other cities at that time (e.g., "Smog Stop", 2018). It was also the year when Poland hosted the highly publicized UN Climate Summit - an international forum devoted to global climate policy (United Nations Climate Change Conference, 2018), followed by numerous youth protests (climate strikes, e.g., Protests of the Youth Strike for Climate in entire Poland, 18 September 2019, see: Protesty Młodzieżowego..., 2019).

We notice that the relationship between the content of the media coverage and the views of society concerns many areas, including environmental protection. Happer and Philo's research $(2013$, p. 333) shows that the media play a facilitating role in the easing through of policy action by repetition and reinforcement of media messages, and the absence of proposed alternatives - and also a possible role in shaping behavior, especially where these are linked to other types of structural support. We wrote about this when the dominant topics in the media influenced the growth of social distance towards immigrants (Kapsa, Kaszkur, \& Trempała, 2017, pp. 222-247). We referred to the results of Artur Lipiński's analysis (2013, p. 22), who noted that news about immigrants is particularly frequent during spectacular dramatic events, and the way in which immigrants are presented is based on the "us vs. them" mentality, combined with the positive evaluation of "us" and the negative evaluation of "them". A consequence is the tendency to put national interests above the value of the integration of states, while the curiosity of another, characteristic of a democratic personality, seems to increasingly give way to authoritarian fears of foreign and xenophobic aggression.

The Internet plays an important role as a platform for social communications and user generated content but it also increases the availability of existing content rather than adding new content and new content formats (van der Wurff, 2008, pp. 68-85). So we can agree that apart from the topics initialized by the users on the Internet there are published also the issues that the traditional media are taking up. The surveyed young people seemed to have been highly influenced by the content present on the Internet, with $91 \%$ of respondents in 2018 indicating the Internet as the main source of information (with such high rate of indications, in 2019, we abandoned this question). The Internet is used by them for watching videos on YouTube, participation in social platforms, and browsing various content on portals, and it may be assumed that these were the channels 
of communication that influenced the world view of young people and their sensitivity to various problems (certainly also to the environment). Between 2018 and 2019, the climate crisis was certainly one of the topics that was "trending" on the Web (an example of this popularity was the environmental challenge on Facebook - \#ShowYourStripes - a Facebook ecological campaign which, with the help of "stripes", showed the changes in average annual temperature in the participants place of residence).

If we compare those conclusion with surveys conducted two decades ago, for example, in Hong Kong (Chan, 1996) or in Oslo (Strandbu \& Skogen, 2000), we see some differences. At that time the attention was paid, in the first case, to the television and school as major sources of environmental information, and in the second one - to the cultural capital. Also such researchers as Fien et al. (2002) focused on the educational reform and the efforts to encourage teachers and others who have influence over young people to develop their own knowledge and skills to be able to teach environmental education effectively. Our survey results indicate that today the most important factor in influencing youth is Internet content. It does not mean that the previous elements are not relevant but the role of school and the social environment should be consistent with the network environment.

\section{CONCLUSIONS}

Our analysis of empirical data concerning the environmental awareness of young people showed the predominance of biocentric/anti-anthropocentric over anthropocentric views in the studied population of final year high school students from Bydgoszcz, Poland. In addition, the 2019 survey showed an increase in responses within the ranges of moderate and extreme biocentrism compared to 2018. This difference is also visible between the indications of respondents regarding the three biggest threats in the world today; both in quantitative and qualitative terms, respondents in 2019 indicated more environmental categories than the year before. This highly significant difference between the two editions of the survey may be attributed to several important events, extensively reported by the media at the time. Although understanding the exact relationship between the content of communications published in the media and the state of environmental awareness of young people would require a broad analysis of the content of media messages, it should be noted the world view of young 
people and their sensitivity to problems seem to depend highly on the content of modern communication channels (mainly the Internet).

\section{REFERENCES:}

Aminrad, Z., Zakaria, S.Z.B.S, \& Hadi, A.S. (2011). Influence of Age and Level of Education on Environmental Awareness and Attitude: Case Study on Iranian Students in Malaysian Universities. The Social Sciences, 6(1), 15-19. DOI: 10.3923/ sscience.2011.15.19.

Badania świadomości ekologicznej [Report of the Polish Ministry of Environment: Adaptation to Climate Change] (2018). Retrieved from: https://www.gov.pl/web/ klimat/badania-swiadomosci-ekologicznej.

Bołtromiuk, A. (2009). Świadomość ekologiczna Polaków - zrównoważony rozwój raport $z$ badań 2009. Warszawa: Instytut na rzecz Ekorozwoju. Retrieved from: https://www.pine.org.pl/wp-content/uploads/pdf/swiad_ekol_polakow.pdf.

Burger, T. (1992). Świadomość ekologiczna: między lękiem a działaniem. Report No. 1/92. Warszawa: Instytut na rzecz Ekorozwoju.

Burger, T. (1997). Optymizm i lokalność. Społeczna świadomość ekologiczna '97. In: W. Baturo, T. Burger, \& A. Kassenberg (eds.). Agenda niespetnionych nadziei. Społeczna ocena realizacji Agendy 21 w Polsce (pp. 8-9). Report No. 4/97. Warszawa: Instytut na rzecz Ekorozwoju.

Burger, T. (2000). Świadomość ekologiczna społeczeństwa polskiego u progu XXI wieku. Report No. 1/2000. Warszawa: Instytut na rzecz Ekorozwoju.

Burger, T. (2005). Świadomość ekologiczna społeczeństwa polskiego. Warszawa: Instytut Gospodarki Przestrzennej i Mieszkalnictwa.

Burger, T., \& Sadowski, A. (1994). Świadomość społeczna: Niderlandy ekologiczne. Report No. 1/94. Warszawa: Instytut na rzecz Ekorozwoju.

Chan, K.K.W. (1996). Environmental Attitudes and Behaviour of Secondary School Students in Hong Kong. The Environmentalist, 16(4), 297-306. DOI: 10.1007/ BF02239656.

Ciążela, H. (2009). Czy ekologia demokratyczna musi być antropocentryczna? Wokół poglądów Luca Ferry'ego. Problemy Ekorozwoju, 4(2), 89-94.

Dunlap, R.E., \& Catton, W.R. (1979). Environmental Sociology. Annual Review of Sociology, 5, 243-273. DOI: 10.1146/annurev.so.05.080179.001331.

Dunlap, R.E., Van Liere, K.D., Mertig, A., \& Jones, R.E. (2000). New Trends in Measuring Environmental Attitudes: Measuring Endorsement of the New Ecological Paradigm: A Revised NEP Scale. Journal of Social Issues, 56(3), 425-442. DOI: 10.1111/0022-4537.00176.

Expose Morawieckiego. Premier o weglu: "to podstawa naszej energetyki, nie chcemy $z$ niego rezygnować" [Prime Minister: "We Don't Want and We Can't Give Up Coal"] (2017). Retrieved from: https://www.money.pl/gospodarka/wiadomosci/artykul/ expose-morawieckiego-wegiel-energetyka,203,0,2393547.html. 
Ganowicz-Bączyk, A. (2009). Spór o etykę środowiskową. Kraków: WAM.

Fien, J., Cheong, I.P.A., Yencken, D., \& Sykes, H. (2002). Youth Environmental Attitudes in Australia and Brunei: Implications for Education. The Environmentalist, 22(3), 205-216. DOI: 10.1023/A:1016571526997.

Fudali, I. (2002). Kultura ekologiczna młodzieży: na przykładzie regionu świętokrzyskiego. Kielce: Wydawnictwo Akademii Świętokrzyskiej.

Gliński, P. (1988). Świadomość ekologiczna społeczeństwa polskiego - dotychczasowe wyniki badań. Kultura i Społeczeństwo, 32(3), 183-196.

Happer, C., \& Philo, G. (2013). The Role of the Media in the Construction of Public Belief and Social Change. Journal of Social and Political Psychology, 1(1). DOI: 10.5964/jspp.v1i1.96.

United Nations Climate Change Conference (2018). Retrieved from: html://cop24.gov. pl.

Kapsa, I., Kaszkur, A., \& Trempała, W. (2017). Dystans społeczny i tendencje autorytarne w postawach młodzieży licealnej - raport z badań empirycznych. In: J. Golinowski, \& S. Sadowski (eds.). Pomiędzy mythos i logos społecznej zmiany (pp. 222-247). Bydgoszcz: Wydawnictwo UKW.

Kortenkamp, K.V., \& Moore, C.F. (2001). Ecocentrism and Anthropocentrism: Moral Reasoning About Ecological Commons Dilemmas. Journal of Environmental Psychology, 21(3), 261-272. DOI: 10.1006/jevp.2001.0205.

Leggewie, C., \& Welzer, H. (2012). Koniec świata, jaki znaliśmy. Klimat, przyszłość i szanse demokracji. Warszawa: Wydawnictwo Krytyki Politycznej.

Lewińska, A. (2019, January 4). Spacerujesz w smogu? To jakbyś przez godzinę wypalit pięć papierosów [Are You Walking in Smog? It's Like You Smoked Five Cigarettes in an Hour]. Retrieved from: https://bydgoszcz.wyborcza.pl/bydgoszcz/7,71270,24330 548,spacerujesz-w-smogu-to-jakbys-przez-godzine-wypalil-piec-papierosow.html.

Lipiński, A. (2013). Media a reprezentacja oraz integracja imigrantów. Warszawa: Fundacja Instytut Spraw Publicznych.

McMillan, M., Hoban, T.J., Clifford, W.B., \& Brant, M.R. (1997). Social and Demographic Influences on Environmental Attitudes. Journal of Rural Social Sciences [Southern Rural Sociology], 13(1), 89-107.

Papuziński, A. (2006). Świadomość ekologiczna w świetle teorii i praktyk (Zarys politologicznego modelu świadomości ekologicznej). Problemy Ekorozwoju, 1(1), 33-40.

Piątek, Z. (1998). Etyka środowiskowa. Nowe spojrzenie na miejsce człowieka w przyrodzie. Kraków: UJ, Instytut Filozofii, Księgarnia Akademicka.

Protesty Młodzieżowego Strajku Klimatycznego w całej Polsce [Protests of the Youth Strike for Climate in Entire Poland] (2019, September 18). Retrieved from: https:// www.rp.pl/Ekologia/190919284-Protesty-Mlodziezowego-Strajku-Klimatycznego-w-calej-Polsce.html.

Skolimowski, H. (1984). Comment. The Dogma of Anti-Anthropocentrism and Ecophilosophy. Environmental Ethics, 6(3), 283-288. DOI: 10.5840/enviroethics19846331. 
„Smog Stop" - miasta pisza do premiera ["Smog Stop" - Cities Write to the Prime Minister] (2018, March 6). Retrieved from: http://www.miasta.pl/aktualnosci/ smog-stop-miasta-pisza-do-premiera.

Strandbu, Å., \& Skogen, K. (2000). Environmentalism among Norwegian Youth: Different Paths to Attitudes and Action? Journal of Youth Studies, 3(2), 189-209. DOI: 10.1080/713684371.

Survey of Environmental Awareness (2014-2019). Retrieved from: https://www.gov.pl/ web/klimat/badania-swiadomosci-ekologicznej.

van der Wurff, R. (2008). The Impact of the Internet on Media Content. In: L. Küng, R.G. Picard, \& R. Towse (eds.). The Internet and the Mass Media (pp. 65-85). London: SAGE Publications Ltd. DOI: 10.4135/9781446216316.n4.

Welzer, H. (2010). Wojny klimatyczne. Warszawa: Wydawnictwo Krytyki Politycznej. Wspólnie pozbądźmy się smogu [Let's Get Rid of Smog Together] (2018, April 4). Retrieved from: http://www.strazmiejska.bydgoszcz.pl/index.php?view=events\&id=807.

Zachem truje? Bezpłatne badania dla mieszkańców Łegnowa i Otorowa [Does Zachem Pollutes? Free Tests for the Citizens of Łęgnowo and Otorowo] (2018). Retrieved from: https://bydgoszcz.wyborcza.pl/bydgoszcz/7,48722,23545052,zachem-trujebezplatne-badania-dla-mieszkancow-legnowa-i-otorowa.html. 